\title{
Letter from the Editor
}

\section{J. Mitchell Miller ${ }^{1}$}

Accepted: 17 December 2020/

Published online: 28 January 2021

(C) Southern Criminal Justice Association 2021

\section{FROM THE EDITOR}

Welcome to Volume 46 of the American Journal of Criminal Justice! AJCJ has experienced considerable change over the last three years with expansion from four to six issues annually, diversification of the editorial board to ensure representation of leading and emerging criminologists and criminal justice scientists, original receipt of and subsequent increases in our Thompson Reuters Social Science Citation Index factor, and broadscale promotion of AJCJ through conference exhibitions - currently replaced by virtual efforts. As we look to continue on an upward trajectory, we invite scholars to view the American as a submission outlet of first choice.

This issue also marks the onset of my second editorial term and change in the editorial office. We are appreciative of the quality work and facilitation of the journal by departing managing editor Stephanie Koskinen who is moving on to doctoral study and welcome our new managing editor Haley Byrnes who joins us after undergraduate studies at the University of Florida. Moving forward and now enabled by over a volume backlog of forthcoming articles and additional timely guest edited issues, we are positioned to select manuscripts for publication that address meaningful topics for criminal justice and applied criminology, feature quality data, and illustrate robust applications of both qualitative and quantitative research techniques. With the virus hopefully ending soon, we also anticipate resuming conference exhibition of AJCJ toward further promoting the journal.

We begin Volume 46 with a guest edited thematic issue on the \#metoo movement in criminology and criminal justice. Experienced Guest Editor Leah Daigle has assembled an impressive range of definitional, empirical, and policy-oriented articles on the movement and related sexual harassment issues that too often emerge across the discipline. There is sure to be something of interest if not keen import for everyone in these timely pieces.

Happy Reading!

J. Mitchell Miller

mitch.miller@unf.edu

1 University of North Florida, Jacksonville, FL, USA 